\title{
PENGARUH PELATIHAN KERJA, LINGKUNGAN KERJA DAN KOMPENSASITERHADAP KEPUASAN KERJA KARYAWAN DI ROY SENTOSO COLLECTION YOGYAKARTA
}

\author{
Candra Ardi Wibowo \\ Fakultas Ekonomi, Universitas Sarjanawiyata Tamansiswa Yogyakarta \\ chandraardi899@gmail.com ${ }^{1} \times$
}

\begin{abstract}
ABSTRAK
Penelitian ini bertujuan untuk mengetahui pengaruh pelatihan kerja, lingkungan kerja, dan kompensasi terhadap kepuasan kerja karyawan di Roy Sentoso Collection Yogyakarta. Penelitian ini menggunakan metode kuantitatif. Populasi dari penelitian ini adalah karyawan Roy Sentoso Collection Yogyakarta dengan jumlah 50 karyawan. Teknik pengambilan sampel adalah sampel jenuh dengan mengambil semua sampel yaitu 50 karyawan. Pengumpulan data pada penelitian ini menggunakan kuesioner dengan skala likert. Analisis data menggunakan SPSS 23 yang terdiri dari uji kualitas data, uji asumsi klasik, uji hipotesis, dan koefisien determinasi. Hasil penelitian menunjukkan bahwa pelatihan kerja dan kompensasi berpengaruh signifikan positif terhadap kepuasan kerja. Sedangkan lingkungan kerja secara parsial tidak berpengaruh signifikan terhadap kepuasan kerja.
\end{abstract}

Kata kunci : pelatihan kerja, lingkungan kerja, kompensasi, dan kepuasan kerja

\begin{abstract}
This study aims to determine the effect of job training, work environment, and compensation on employee job satisfaction at Roy Sentoso Collection Yogyakarta. This research uses quantitative methods. The population of this study were employees of the Roy Sentoso Collection Yogyakarta with a total of 50 employees. The sampling technique is saturated sample by taking all samples, namely 50 employees. Collecting data in this study using a questionnaire with a Likert scale. Data analysis using SPSS 23 which consists of data quality test, classic assumption test, hypothesis test, anddetermination coefficient. The results showed that job training and compensation had a significant positive effect on job satisfaction. While the work environment partially does not have a significant effect on job satisfaction.
\end{abstract}

Keywords: job training, work environment, compensation, and job satisfaction

\footnotetext{
${ }^{1} \rtimes:$ Corresponding author: chandraardi899@gmail.com
} 


\section{PENDAHULUAN}

Perkembangan zaman yang terjadi secara terus menerus dan persaingan organisasi perusahaan yang semakin nyata seakan menjadi tantangan tersendiri bagi organsisasi perusahaan yang telah ada maupun yang baru memulai. Adanya suatu organisasi perusahaan pasti berkaitan erat dengan sumber daya manusia yang merupakan aset yang paling penting dan berpengaruh dalam aktivitas suatu organisasi perusahaan.

Dalam organisasi perusahaan, sumber daya manusia juga senantiasa harus meningkatkan kompetensinya, seiring dengan perkembangan era globalisasi dan berperan penting bagi setiap individu dan kelompok. Manajemen sumber daya manusia yang baik dapat membantu perusahaan untuk mendapatkan karyawan yang tepat sesuai dengan yang dibutuhkan. Hal ini dimaksudkan agar karyawan bekerja secara efektif dan efisien untuk mencapai tujuan perusahaan dan berdampak pada kepuasan kerja karyawan.

Seiring berkembangnya suatu usaha, maka semakin kompleks dan rumit pengelolaannya. Untuk itu setiap perusahaan harus mampu selalu berkembang agar memiliki suatu keunggulan yang kompetitif serta tercapainya kepuasan karyawan. Seluruh aspek dan sumber daya yang terdapat di perusahaan merupakan faktor-faktor yang sangat diperlukan untuk hal tersebut tergantung pada pelatihan kerja, lingkungan kerja, dan kompensasi.

Pelatihan merupakan proses untuk mempertahankan atau memperbaiki keterampilan karyawan untuk menghasilkan pekerjaan yang efektif (Bangun dalam Trawardani, 2015). Pelatihan selalu dibutuhkan baik bagi karyawan baru maupun karyawan lama. Untuk karyawan baru wajib diberi pelatihan agar bisa memahai tugas sesuai dengan jabatan, sedangkan untuk karyawan lama perlu mengikuti pelatihan untuk mempersiapkan diri agar mampu berkembang untuk menyelesaikan pekerjaan dan untuk promosi jabatan.

Lingkungan kerja merupakan komponen sangat penting dalam mendukung terciptanya kepuasan kerja karyawan. Apabila karyawan berada dalam lingkungan kerja yang nyaman akan meningkatkan kepuasan dalam bekerja sehingga karyawan dapat meningkatkan kinerjanya. Sebaliknya, kepuasan akan menurun apabila kurangnya kenyamanan lingkungan kerja sehingga berdampak pada menurunnya kinerja karyawan. Menurut Sunyoto (2013) mulai dari penerangan, sirkulasi udara, dan keamanan serta hubungan karyawan dengan sesama karyawan dan hubungan karyawan dengan atasan (interaksi sosial) merupakan faktor pendukung keberhasilan dan kemajuan perusahaan serta dapat memberi pengaruh terhadap kegairahan yang menimbulkan perasaan senang atau tidak senang karyawan terhadap pekerjaannya.

Pemberian kompensasi bagi karyawan juga akan memberikan kepuasan dalam bekerja bagi setiap karyawan yang kemudian hal tersebut dapat menjadi motivasi bagi karyawan untuk bekerja lebih keras, kreatif dan terampil yang pada akhirnya berdampak baik bagi perusahaan. Kompensasi diberikan sebagai bentuk nilai balas jasa atas apa yang diberikan oleh karyawan terhadap perusahaan. Kompensasi harus diberikan secara adil dan merata kepada karyawan yang dirasa memberikan prestasi yang baik bagi perusahaan.

Berdasarkan pemaparan diatas, peneliti tertarik untuk melakukan penelitian di Roy Sentoso Collection Yogyakarta. Roy Sentoso Collection merupakan salah satu perusahaan yang bergerak dalam bidang tekstil terbesar di Kabupaten Bantul. Perusahaan ini telah berdiri sejak tahun 1991, sampai saat ini memiliki dua cabang, cabang pertama berada di Jl. Brajan RT 03 RW 04, Tamantitro, Kasihan, Bantul, Yogyakarta dan cabang kedua berada di Jl. KH. Ahmad Dahlan No. 33, Ngupasan, Kec. Gondomanan, Kota Yogyakarta. Roy Sentoso Collection menjadi salah satu jujukan utama ketika orang akan membuat pakaian atau merchandise dalam jumlah banyak. Pelayanan yang ramah, bahan yang berkualitas, dan harga yang terjangkau menjadi alasan orang datang ke Roy Sentoso Collection. 


\section{TINJAUAN PUSTAKA}

\section{Manajemen Sumber Daya Manusia}

Menurut Hasibuan (2011) manajemen sumber daya manusia adalah ilmu dan seni mengatur hubungan dan peranan tenaga kerja agar efektif dan efisien membantu terwujudnya tujuan perusahaan, karyawan, dan masyarakat. Manajemen sumber daya manusia merupakan pendekatan terhadap manajemen manusia (Sunyoto, 2013). Pendekatan terhadap manajemen mausia tersebut didasarkan pada nilai manusia dalam hubugannya dengan organisasi. Manusia merupakan sumber daya yang penting dalam organisasi, disamping itu efektivitas organisasi ditentukan oleh manajemen.

\section{Pelatihan Kerja}

Pelatihan kerja menurut Widodo (2015) merupakan serangkaian aktivitas individu dalam meningkatkan keahlian dan pengetahuan secara sistematis sehingga mampu memiliki kinerja yang professional di bidangnya. Berdasarkan pengertian tersebut, pelatihan kerja berarti suatu perubahan yang sistematis dari knowledge, skill, attitude, dan behaviour yang terus mengalami peningkatan yang dimiliki oleh setiap karyawan dengan itu dapat mewujudkan sasaran yang ingin dicapai oleh suatu organisasi atau perusahaan dalam pemenuhan standar Sumber Daya Manusia yang diinginkan. Menurut Mondy (2008) pelatihan dan pengembangan (training and development) adalah jantung dari upaya berkelanjutan untuk meningkatkan kompetensi karyawan dan kinerja organisasi.

\section{Lingkungan Kerja}

Menurut Nitisemito (1996) lingkungan kerja adalah segala sesuatu yang ada di sekitar para pekerja dan dapat mempengaruhi dirinya dalam menjalankan tugas yang dibebankan. Baik dan buruknya lingkungan akan berdampak pada diri karyawan itu sendiri dalam menjalankan tugasnya. Seperti yang dikemukakan oleh Reksohadiprodjo dan Gitosudarmo (2009), lingkungan kerja adalah segala sesuatu yang ada di sekitar pekerja yang dapat mempengaruhi dalam bekerja meliputi pengaturan penerangan, pengontrolan suara gaduh, pengaturan kebersihan tempat kerja dan pengaturan keamanan tempat kerja. Pendapat yang dikemukakan oleh Rivai (2004) lingkungan kerja merupakan elemen-elemen organisasi sebagai sistem sosial yang mempunyai pengaruh kuat di dalam pembentukan perilaku individu pada organisasi dan berpengaruh terhadap prestasi.

\section{Kompensasi}

Menurut Simamora (1995) kompensasi merupakan istilah luas berkaitan dengan imbalan-imbalan finansial (financial reward) yang diterima oleh orang-orang melalui hubungan kepegawaian mereka dengan sebuah organisasi. Kompensasi menurut Sastrohadiwiryo (2003) adalah balas jasa diberikan oleh perusahaan kepasa tenaga kerja, karena tenaga kerja memberikan sumbangan tenaga dan pikiran demi kemajuan perusahaan guna mencapai tujuan yang telah ditetapkan baik dalam jangka pendek maupun jangka panjang.

\section{Pengaruh Pelatihan terhadap kepuasan kerja karyawan}

Kepuasan kerja dipengaruhi banyak faktor seperti kepemimpinan, budaya organisasi, motivasi dan disiplin kerja (Asriani et al., 2020; Qarismail dan Prayekti, 2020). Kepuasan kerja juga dapat dipengaruhi oleh pelatihan. Pelatihan merupakan aktivitas yang paling umum dilakukan oleh organisasi, karena melalui pelatihan seorang karyawan dibekali untuk menjadi terampil dan produktif (Dessler, 2010). Hal ini perlu mendapatkan perhatian dari manajemen perusahaan dalam upaya peningkatan kepuasan kerja karyawan, karena dengan 
adanya kepuasan kerja bagi karyawan, akan berdampak pada tingkat produktivitas kerja, yang tentunya akan membantu tingkat pelayanan kepada konsumen. Untuk itu perlu dilakukan pelatihan-pelatihan kepada karyawan agar semakin terampil dalam melakukan tugasnya. Berdasarkan penelitian yang dilakukan Lodjo (2013) menunjukkan bahwa pelatihan berpengaruh secara signifikan dan positif terhadap kepuasan kerja karyawan. Mengacu pada hal tersbut maka dirumuskan hipotesis 1 sebagai berikut:

H1 : Pelatihan berpengaruh positif signifikan terhadap kepuasan kerja karyawan di Roy Sentoso Collection Yogyakarta

\section{Pengaruh Lingkungan Kerja terhadap kepuasan kerja karyawan}

Menurut (Nitisemito, 1996) lingkungan kerja adalah segala sesuatu yang ada di sekitar pekerja, yang dapat mempengaruhi seorang pekerja dalam menjalankan tugas-tugas yang diberikan. Pada dasarnya pengertian lingkungan berkaitan dengan elemen-elemen yang ada disekitar perusahaan yang berdampak secara langsung maupun tidak langsung terhadap perusahaan.

Apabila lingkungan di perusahaan kurang mendukung seperti suasana kerja, keamanan kerja, fasilitas kerja, serta kurangnya hubungan antar atasan dan bawahan, maka akan menurunkan kepuasan kerja karyawan. Masalah tersebut adalah dapat diatasi dengan menciptakan lingkungan kerja melalui pengikatan hubungan yang harmonis dengan atasan, rekan kerja, maupun bawahan. Selain itu dukungan sarana dan prasarana yang memadai di tempat bekerja akan membawa dampak yang positif bagi karyawan, sehingga kepuasan karyawan dapat meningkat.

Penelitian yang dilakukan Wibowo et al. (2014) menunjukkan bahwa lingkungan kerja berpengaruh signifikan dan positif terhadap kepuasan kerja. Mengacu pada hal tersbut maka dirumuskan hipotesis sebagai berikut:

H2 : Lingkungan Kerja berpengaruh positif signifikan terhadap kepuasan kerja karyawan di Roy Sentoso Collection Yogyakarta

\section{Pengaruh Kompensasi terhadap kepuasan kerja karyawan}

Kompensasi adalah semua pendapatan yang berbentuk uang, barang langsung maupun tidak langsung yang diterima karyawan sebagai imbalan atas jasa yang diberikan kepada perusahaan (Hasibuan, 2011). Semakin besar kompensasi yang diberikan maka kepuasan kerja karyawan akan semakin tinggi, sebaliknya apabila kompensasi yang diberikan oleh perusahaan kecil maka kepuasan kerja karyawan akan semakin rendah. Penelitian yang dilakukan menunjukkan bahwa kompensasi berpengaruh signifikan dan positif terhadap kepuasan kerja. Mengacu pada hal tersbut maka dirumuskan hipotesis sebagai berikut :

H3 : Kompensasi berpengaruh positif signifikan terhadap kepuasan kerja karyawan di Roy Sentoso Collection Yogyakarta 


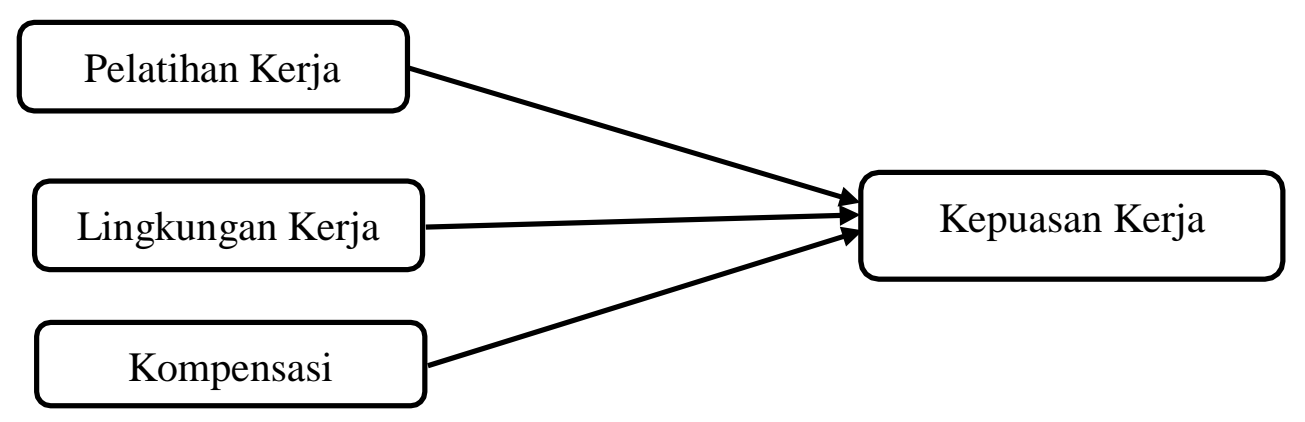

Gambar 1. Kerangka Pikir Penelitian

\section{METODE PENELITIAN}

Penelitian ini merupakan penelitian asosiatif kausal yaitu penelitian yang digunakan untuk mengetahui hubungan sebab akibat antara variabel independen dan variabel dependen. Jenis penelitian ini adalah deskriptif kuantitatif. Menurut Martoyo (1987) penelitian kuantitatif yaitu penelitian yang dilakukan dengan mengumpulkan data berupa angka yang kemudian data tersebut diolah untuk mendapatkan suatu informasi dibalik angka-angka tersebut.

\section{Definisi Operasional dan Indikator Variabel Penelitian}

Variabel penelitian dalam penelitian ini yaitu menggunakan variabel dependen dan variabel independen. Variabel dependen dalam penelitian ini yaitu kepuasan kerja. Kepuasan kerja adalah keadaan emosional yang menyenangkan atau tidak menyenangkan bagi para karyawan memandang pekerjaan mereka. Hal tersebut terlihat dalam sikap positif karyawan terhadap pekerjaan dan segala sesuatu yang dihadapi di lingkungan kerjanya. Variabel dependen ini dapat diukur dengan promosi, pengawasan, rekan kerja, dan pekerjaan itu sendiri. Dalam penelitian ini, variabel independen yang digunakan ada tiga, yaitu pelatihan kerja, lingkungan kerja, dan kompensasi.

Pelatihan kerja merupakan serangkaian aktivitas individu dalam meningkatkan keahlian dan pengetahuan secara sistematis sehingga mampu memiliki kinerja yang professional di bidangnya (Widodo, 2015). Berdasarkan pengertian tersebut, pelatihan kerja berarti suatu perubahan yang sistematis dari knowledge, skill, attitude, dan behaviour yang terus mengalami peningkatan yang dimiliki oleh setiap karyawan dengan itu dapat mewujudkan sasaran yang ingin dicapai oleh suatu organisasi atau perusahaan dalam pemenuhan standar sumber daya manusia yang diinginkan. Variabel ini diukur dengan menggunakan pengetahuan, kemampuan berpikir, sikap, dan kecakapan. Variabel lingkungan kerja menurut Nitisemito (1996) adalah segala sesuatu yang ada di sekitar para pekerja dan dapat mempengaruhi dirinya dalam menjalankan tugas yang dibebankan. Baik dan buruknya lingkungan akan berdampak pada diri karyawan itu sendiri dalam menjalankan tugasnya. Variabel ini diukur dengan menggunakan suasana kerja, hubungan antar rekan kerja, dan fasilitas kerja.

Variabel independen terakhir yaitu kompensasi. Kompensasi adalah semua pendapatan yang diterima karyawan yang berbentuk uang, barang langsung atau tidak langsung yang merupakan bentuk biaya yang harus dikeluarkan perusahaan dengan harapan memperoleh imbalan berupa prestasi kerja dari karyawan. Kompensasi berbentuk uang artinya kompensasi di bayar dalam bentuk uang kartal kepada karyawan yang bersangkutan. Kompensasi berbentuk barang artinya kompensasi dibayar dengan barang (Hasibuan, 2011). Variabel ini diukur dengan menggunakan gaji, fasilitas, tunjangan. 


\section{Sampel}

Sampel dari penelitian ini adalah semua Karyawan Roy Sentoso Collection Yogyakarta yang berjumlah 50 karyawan yang bekerja di Roy Sentoso Collection Yogyakarta. Teknik pengambilan sampel yaitu dengan teknik sampling jenuh. Teknik sampling jenuh adalah teknik penentuan sampel bila semua anggota populasi digunakan sampel.

\section{Teknik Pengumpulan Data}

Teknik pengumpulan data dalam penelitian ini menggunakan kuisioner. Survey dilakukan dengan cara mengadakan peninjauan langsung kepada karyawan yang menjadi objek untuk mendapatkan data primer. Menurut Arikunto (2013) data primer adalah data yang dikumpulkan secara langsung dari objek penelitian melalui kuisioner kepada responden penelitian. Kuesioner ini berisi tentang karakteristik responden, pelatihan kerja perusahaan, lingkungan kerja perusahaan, kompensasi perusahaan, dan kepuasan kerja responden. Kuesioner disusun dengan memberikan lima skala penliaian yaitu menggunakan skala likert.

\section{Tempat Pengambilan Data}

Penelitian ini dilakukan di wilayah Yogyakarta dengan sasaran pegawai yang bekerja di Roy Sentoso Collection Yogyakarta yang beralamat di Jl. Brajan RT 03 RW 14, Tamantirto, Kasihan, Bantul, Yogyakarta, 55184.

\section{Teknik Analisis Data}

Analisis data menggunakan teknik deskriptif yaitu suatu metode yang bersifat menjelaskan data yang ada dihubungkan dengan teori-teori yang terkait dengan objek penelitian, untuk selanjutnya diambil kesimpulan. Analisis ini digunakan untuk menganalisa data satu persatu berdasarkan jawaban responden dari kuesioner yang diberikan selama penelitian berlangsung. Telah disampaikan pada sub-bab Pengembangan Instrumen Penelitian, skor jawaban responden dalam penelitian ini terdiri dari 5 alternatif jawaban yang diberi skor 1 sampai 5. Berdasarkan skor tersebut, selanjutnya data yang terkumpul dapat dikelompokkan berdasarkan kategori sehingga dapat dikertahui kualitasnya sesuai dengan proporsi yang ada.

\section{Uji Kualitas Data}

Uji yang digunakan untuk menguji apakah angket tersebut layak dan sesuai indikator yang ada pada variabel independen dan dependen dengan menggunakan uji validitas dan realibilitas. Uji validitas digunakan untuk mengukur sah atau tidaknya suatu butir pertanyaan. Skala butir perntanyaan disebut valid, jika melakukan apa yang seharusnya diukur dengan cara melakukan uji signifikansi koefisien korelasi pada taraf signifikan 0,05 yang artinya suatu item dianggap valid jika berkorelasi signifikan terhadap skor total item (Sunyoto, 2013). Dalam penelitian ini dilakukan uji validitas yang menggunakan metode Corrected item-Total correlations. Jika $\mathrm{r}$ hitung $>\mathrm{r}$ tabel maka dianggap instrument memiliki validitas yang baik.

Untuk uji reliabilitas menunjuk pada satu pengertian bahwa suatu instrumen cukup dapat dipercaya untuk digunakan sebagai alat pengumpul data karena instrumen tersebut cukup baik (Arikunto, 2013). Uji reliabilitas dimaksudkan untuk melihat sejauh mana hasil suatu pengukuran instrumen dapat dipertanggung jawabkan. Suatu kuesioner dikatakan reliabel atau handal jika jawaban seseorang terhadap pernyataan adalah konsisten atau stabil dari waktu ke waktu dan suatu variabel dikatakan reliabel jika memberi nilai Cronbach's Alpha > 0,60 (Priyatno, 2014). 


\section{Uji Asumsi Klasik}

Uji asumsi klasik dalam penelitian ini terdiri dari uji normalitas, uji multikolinearitas, dan uji heteroskedastisitas. Uji normalitas bertujuan untuk mengetahui bahwa sebaran data penelitian berdistribusi normal atau tidak. Metode yang digunakan untuk menguji normalitas adalah menggunakan Metode One Sample Kolmogorov Smirnov Test jika nilai signifikan lebih besar dari 0,05 atau 5\% maka data berdistribusi normal. Jika nilai signifikan lebih kecil dari 0,05 atau 5\% maka data tidak berdistribusi normal (Priyatno, 2014).

Uji multikolinearitas bertujuan untuk mengetahui apakah dalam model regresi ditemukan adanya korelasi antar variabel bebas (independen). Model regresi yang baik seharusnya tidak terjadi korelasi diantara variabel independen. Untuk mendeteksi adanya multikolinearitas adalah dengan menggunakan nilai Variance Inflation Factor (VIF). Jika VIF lebih kecil dari 5, maka dalam model tidak terdapat multikolinearitas. Uji yang terakhir yaitu uji heteroskedastisitas bertujuan untuk menguji apakah dalam model regresi terjadi ketidaksamaan varian dari residual satu pengamatan ke pengamatan yang lain tetap, maka disebut Homoskedastisitas sedangkan jika berbeda disebut dengan Heteroskedastisitas (Ghozali, 2016).

\section{Pengujian Hipotesis}

Uji hipotesis bertujuan untuk mengetahui apakah terdapat pengaruh yang jelas dan dapat dipercaya antara variabel independen (Pelatihan, Lingkungan Kerja dan Kompensasi) terhadap variabel dependen (Kepuasan Kerja). Metode analisis data terdiri dari uji statistik (t-test) dan uji koefisien determinasi (R2).

\section{HASIL DAN PEMBAHASAN}

Berdasarkan tabel 1 dapat disimpulkan bahwa responden dalam penelitian ini berdasarkan jenis kelamin dikelompokkan kedalam dua jenis, yaitu laki-laki dan perempuan. Sebanyak 50 responden yang dijadikan sampel dalam penelitian ini, 29 diantaranya berjenis kelamin laki-laki $(58,0 \%)$. Sisanya sebesar 21 responden berjenis kelamin perempuan $(42,0$ $\%)$. Hal tersebut berarti kuesioner dalam penelitian ini didominasi oleh karyawan berjenis kelamin laki-laki.

Tabel 1. Karakteristik Responden Berdasarkan Jenis Kelamin

\begin{tabular}{cccc}
\hline Karakteristik & Keterangan & Jumlah & Presentase (\%) \\
\hline Jenis & Laki-Laki & 29 & $58,0 \%$ \\
Kelamin & Perempuan & 21 & $42,0 \%$ \\
\hline
\end{tabular}

Tabel 2 menunjukkan gambaran responden berdasarkan tingkat usia yang dikelompokkan menjadi usia 20-35 tahun, 36-45 tahun dan usia diatas 45 tahun (>45). Sebanyak 11 responden memiliki usia anatara 20-35 tahun, 25 responden memiliki usia antara 36-45 tahun dan 14 responden berada pada usia $>45$ tahun. Dapat disimpulkan bahwa responden didominasi usia 25 tahun $(50,0 \%)$.

Tabel 2. Karakteristik Responden Berdasarkan Usia

\begin{tabular}{cccc}
\hline Karakteristik & Keterangan & Jumlah & Presentase (\%) \\
\hline Usia & $20-35$ & 11 & $22,0 \%$ \\
& $36-45$ & 25 & $50,0 \%$ \\
& $>45$ & 14 & $28,0 \%$ \\
\hline
\end{tabular}


Berdasarkan Tabel 3 menunjukkan bahwa responden memiliki pendidikan terakhir SLTA/Sederajat 43 responden dengan presentase $86,0 \%$, dan responden yang memiliki pendidikan terakhir Sarjana (S1) 7 responden (14,0\%). Dapat disimpulkan bahwa responden didominasi pendidikan terakhir SLTA/Sederajat yang berjumlah 43 responden $(86,0 \%)$.

Tabel 3. Karakteristik Responden Berdasarkan Pendidikan

\begin{tabular}{clcc}
\hline Karakteristik & Keterangan & Jumlah & Presentase (\%) \\
\hline Pendidikan & SLTA/Sederajat & 43 & $86,0 \%$ \\
& Diploma & - & - \\
& Sarjana (S1) & 7 & $14,0 \%$ \\
\hline
\end{tabular}

Berdasarkan tabel 4 menunjukkan responden yang memiliki masa kerja 1-3 tahun sebanyak 21 responden $(42,0 \%)$, responden yang memiliki masa kerja 4-6 tahun sebanyak 13 responden $(26,0 \%)$, dan responden yang memiliki masa kerja $>6$ tahun sebanyak 16 responden $(32,0 \%)$. Dapat disimpulkan bahwa responden didominasi masa kerja 1-3 tahun sebanyak 21 responden $(42,0 \%)$.

Tabel 4. Karakteristik Responden Berdasarkan Lama Bekerja

\begin{tabular}{cccc}
\hline Karakteristik & Keterangan & Jumlah & Presentase (\%) \\
\hline Lama Bekerja & $1-3$ tahun & 21 & $42,0 \%$ \\
& 4-6 tahun & 13 & $26,0 \%$ \\
& $>6$ tahun & 16 & $32,0 \%$ \\
\hline
\end{tabular}

\section{Analisis Data}

Nilai $r_{\text {hitung }}$ yang kurang dari $r_{\text {tabel }}$ menunjukkan pernyataan tidak mampu mengukur variabel yang ingin diukur, dan jika $r_{\text {hitung }}>r_{\text {tabel }}$ maka pernyataan tersebut valid (Ghozali, 2013). Dilihat dari hasil tabel 5 menunjukkan bahwa nilai korelasi tiap skor butir pernyataan variabel yang ada di dalam penelitian, di atas $r_{\text {tabel }}$ menunjukkan angka $(0,278)$ yang berarti valid. Artinya, semua item pernyataan mampu mengukur variabel pelatihan kerja, lingkungan kerja, kompensasi, dan kepuasan kerja.

Tabel 5. Hasil Uji Validitas

\begin{tabular}{ccccc}
\hline Variabel & Pernyataan & r hitung & r tabel & Validitas \\
\hline Pelatihan Kerja & 1 & 0,626 & 0,278 & Valid \\
(X1) & 2 & 0,662 & 0,278 & Valid \\
& 3 & 0,589 & 0,278 & Valid \\
& 4 & 0,730 & 0,278 & Valid \\
& 5 & 0,428 & 0,278 & Valid \\
Lingkungan & 6 & 0,517 & 0,278 & Valid \\
Kerja & 7 & 0,446 & 0,278 & Valid \\
(X2) & 1 & 0,590 & 0,278 & Valid \\
& 3 & 0,874 & 0,278 & Valid \\
& 4 & 0,531 & 0,278 & Valid \\
& 5 & 0,701 & 0,278 & Valid \\
& 6 & 0,586 & 0,278 & Valid \\
& 7 & 0,763 & 0,278 & Valid \\
& & 0,491 & 0,278 & Valid
\end{tabular}


Tabel 5. Hasil Uji Validitas (lanjutan)

\begin{tabular}{ccccc}
\hline Variabel & Pernyataan & r hitung & r tabel & Validitas \\
\hline Kompensasi & 1 & 0,755 & 0,278 & Valid \\
(X3) & 2 & 0,763 & 0,278 & Valid \\
& 3 & 0,910 & 0,278 & Valid \\
Kepuasan Kerja & 4 & 0,883 & 0,278 & Valid \\
(Y) & 1 & 0,727 & 0,278 & Valid \\
& 2 & 0,846 & 0,278 & Valid \\
& 3 & 0,814 & 0,278 & Valid \\
& 4 & 0,587 & 0,278 & Valid \\
& 5 & 0,514 & 0,278 & Valid \\
\hline
\end{tabular}

Ghozali (2005) mendefinisikan suatu kuesioner dikatakan reliabel jika jawaban seseorang terhadap pernyataan adalah konsisten dan suatu variabel dikatakan reliabel jika memberikan nilai Cronbach's Alpha $>0,60$. Tabel 6 menujukkan bahwa setiap variabel yang digunakan dalam penelitian ini dinyatakan reliabel. Artinya semua jawaban responden sudah konsisten dalam menjawab setiap item pernyataan yang mengukur masing-masing variabel. Variabel tersebut merupakan pelatihan kerja, lingkungan kerja, kompensasi, dan kepuasan kerja

Tabel 6. Hasil Uji Reliabilitas

\begin{tabular}{|l|c|c|c|}
\hline \multicolumn{1}{|c|}{ Variabel } & $\begin{array}{c}\text { Cronbach's } \\
\text { Alpha }\end{array}$ & Nilai Kritis & Keterangan \\
\hline Pelaithan Kerja & 0,648 & 0,60 & Reliabel \\
\hline Lingkungan Kerja & 0,770 & 0,60 & Reliabel \\
\hline Kompensasi & 0,831 & 0,60 & Reliabel \\
\hline Kepuasan Kerja & 0,804 & 0,60 & Reliabel \\
\hline
\end{tabular}

\section{Uji Asumsi Klasik}

Tabel 7 menunjukkan bahwa nilai Kolmogorov-Smirnov Test 0,200 > 0,05. Dengan demikian, dapat disimpulkan bahwa hasil pada penelitian ini terdistribusi normal.

Tabel 7. Uji Normalitas

\begin{tabular}{ccc}
\hline Kolmogorov-Smirnov Test & Sig & Keterangan \\
\hline Asymp. Sig. (2- tailed) & 0,200 & Data Berdistribusi Normal \\
\hline
\end{tabular}

Tabel 8 menunjukkan nilai tolerance lebih besar dari 0,10 dan nilai VIF lebih kecil dari 5. Hal ini berarti menunjukkan bahwa tidak adanya masalah pada multikolinearitas dalam model regresi.

Tabel 8. Uji Multikolinearitas

\begin{tabular}{llrc}
\hline & \multicolumn{3}{c}{ Coefficients } \\
\hline \multicolumn{1}{c}{ Model } & Tolerance & VIF & Keterangan \\
\hline Pelatihan Kerja & 0,813 & 1,230 & Tidak ada Multikolinearitas \\
Lingkungan Kerja & 0,611 & 1,636 & Tidak ada Multikolinearitas \\
Kompensasi & 0,564 & 1,775 & Tidak ada Multikolinearitas \\
\hline
\end{tabular}


Pada Tabel 9 diperoleh bahwa seluruh nilai variabel bebas mempunyai nilai probabilitas (sig) yang lebih besar dari taraf signifikan 0,05 . Hal ini dapat disimpulkan bahwa tidak terjadi gejala heteroskedastisitas.

Tabel 9. Uji Heteroskedastisitas

\begin{tabular}{lrc}
\hline \multicolumn{1}{c}{ Model } & Sig & Keterangan \\
\hline Pelatihan Kerja & 0,344 & Bebas dari Heteroskedastisitas \\
Lingkungan Kerja & 0,591 & Bebas dari Heteroskedastisitas \\
Kompensasi & 0,575 & Bebas dari Heteroskedastisitas \\
\hline
\end{tabular}

\section{Uji Hipotesis} Berganda.

Tabel 10 menunjukkan hasil uji hipotesis penelitian menggunakan Regresi Linear Tabel 10. Hasil Uji t

\begin{tabular}{lccccl}
\hline \multirow{1}{*}{ Model } & \multicolumn{2}{c}{$\begin{array}{c}\text { Unstandardized } \\
\text { Coefficients }\end{array}$} & T & Sig & Keterangan \\
\cline { 2 - 4 } & B & Std Error & & & \\
\hline (Constant) & 1,471 & 3,853 & 0,382 & 0,704 & \\
Pelatihan Kerja & 0,320 & 0,133 & 2,395 & 0,021 & Berpengaruh \\
Lingkungan Kerja & 0,082 & 0,136 & 0,604 & 0,549 & Tidak Berpengaruh \\
Kompensasi & 0,632 & 0,153 & 4,142 & 0,000 & Berpengaruh \\
\hline
\end{tabular}

a. Pengaruh Pelatihan Kerja terhadap Kepuasan Kerja

Hasil penelitian menunjukkan pelatihan kerja berpengaruh signifikan positif terhadap kepuasan kerja. Variabel pelatihan kerja memiliki t hitung sebesar 2,395 dengan tingkat signifikansi 0,021 . Tingkat signifikansi tersebut kurang dari 0,05 berarti bahwa pelatihan kerja berpengaruh signifikan positif terhadap kepuasan kerja karyawan di Roy Sentoso Collection Yogyakarta. Hasil ini sejalan dengan penelitian yang dilakukan oleh Lodjo (2013) yang menyatakan bahwa hasil penelitian menunjukkan bahwa pelatihan kerja berpengaruh positif dan signifikan terhadap kepuasan kerja karyawan.

b. Pengaruh Lingkungan Kerja terhadap Kepuasan Kerja

Hasil penelitian menunjukkan lingkungan kerja tidak berpengaruh signifikan terhadap kepuasan kerja. Variabel lingkungan kerja memiliki t hitung sebesar 0,604 dengan tingkat signifikansi 0,549. Tingkat signifikansi tersebut lebih besar dari 0,05 berarti bahwa lingkungan kerja tidak berpengaruh signifikan terhadap kepuasan kerja karyawan Roy Sentoso Collection Yogyakarta. Hasil penelitian ini berlawanan dengan hipotesis kedua yang diajukan. Hasil tersebut bertolak belakang dengan penelitian yang dilakukan oleh Wibowo et al. (2014) yang menyatakan bahwa lingkungan berpengaruh positif dan signifikan terhadap kepuasan kerja. Akan tetapi hasil tersebut sejalan dengan penelitian yang dilakukan oleh Lumentut dan Dotulong (2015) yang menyatakan bahwa lingkungan kerja tidak mempunyai pengaruh signifikan positif terhadap kepuasan kerja.

c. Pengaruh Kompensasi terhadap Kepuasan Kerja

Hasil penelitian menunjukkan kompensasi berpengaruh signifikan positif terhadap kepuasan kerja. Variabel kompensasi memiliki t hitung sebesar 4,142 dengan tingkat signifikansi 0,000. Tingkat signifikansi tersebut kurang dari 0,05 berarti bahwa 
kompensasi berpengaruh signifikan positif terhadap kepuasan kerja karyawan di Roy Sentoso Collection Yogyakarta. Hasil ini sejalan dengan penelitian yang dilakukan oleh Potale dan Uhing (2015) yang menyatakan bahwa hasil penelitian menunjukkan bahwa kompensasi berpengaruh positif dan signifikan terhadap kepuasan kerja karyawan.

Tabel 11 dapat dilihat bahwa nilai $\mathrm{R}$ sebagai nilai koefisien korelasi sebesar 0,744 yang berarti variabel pelatihan kerja, lingkungan kerja, dan kompensasi memiliki keeratan korelasi yang kuat terhadap variabel kepuasan kerja. Nilai R Square atau koefisien determinasi pada penelitian ini sebesar 0,554 yang berarti besarnya kontribusi antara variabel pelatihan kerja, lingkungan kerja, dan kompensasi memiliki keeratan korelasi yang kuat terhadap variabel kepuasan kerja sebesar 55,4\% sedangkan sisanya 44,6\% dipengaruhi oleh faktor-faktor lain yang tidak diamati dalam penelitian ini.

Tabel 11. Hasil Uji Koefisein Korelasi dan Determinasi

\begin{tabular}{ccccc} 
Model & R & R Square & Adjusted R Square & Std. Error of the Estimate \\
\hline 1 & 0,744 & 0,554 & 0,525 & 2,124 \\
\hline
\end{tabular}

\section{PENUTUP}

Penelitian ini dilakukan terhadap seluruh karyawan dari Roy Sentoso Collection Yogyakarta yang berjumlah 50 responden. Penelitian ini menguji perngaruh pelatihan kerja, lingkungan kerja, dan kompensasi terhadap kepuasan kerja karyawan Roy Sentoso Collection Yogyakarta. Berdasarkan hasil analisis data pada penelitian mengenai pelatihan kerja, lingkungan kerja, dan kompensasi terhadap kepuasan kerja karyawan di Roy Sentoso Collection maka dapat diambil kesimpulan sebagi berikut :

a. Pelatihan kerja berpegaruh signifikan positif terhadap kepuasan kerja karyawan di Roy Sentoso Collection Yogyakarta. Hal ini ditunjukkan dengan dengan variabel pelatihan kerja mempunyai tingkat signifikan sebesar 0,021 dan thitung 2,395. Hal tersebut berarti tingkat signifikan lebih kecil dari $0,05(0,021<0,05)$ dan $t$ hitung $>$ $t$ tabel $(2,395>2,0129)$.

b. Lingkungan kerja tidak berpengaruh terhadap kepuasan kerja karyawan di Roy Sentoso Collection Yogyakarta. Hal ini ditunjukkan dengan variabel lingkungan kerja mempuyai tingkat signifikan sebesar 0,549 dan t hitung 0,604. Hal tersebut berarti tingkat signifikan lebih besar dari $0,05(0,549>0,05)$ dan $\mathrm{t}$ hitung $<\mathrm{t}$ tabel $(0,604<2,012)$.

c. Kompensasi berpegaruh signifikan positif terhadap kepuasan kerja karyawan di Roy Sentoso Collection Yogyakarta. Hal ini ditunjukkan dengan nilai t hitung 4,142 dan tingkat signifikan sebesar 0,000 . Yang berarti tingkat signifikan lebih kecil dari 0,05 $(0,000<0,05)$ dan $t$ hitung lebih besar dari t tabel $(4,142>2,012)$.

\section{Keterbatasan Penelitian}

Penelitian ini memiliki keterbatasan dan diharapkan dapat memberikan gambaran untuk penelitian selanjutnya. Penelitian ini hanya mencakup tiga variabel untuk mengetahui pengaruh terhadap kepuasan kerja karyawan yaitu pelatihan kerja, lingkungan kerja, dan kompensasi. Penelitian ini hanya menggunakan satu sumber data penelitian yaitu kuesioner. Dengan demikian kesimpulan yang dapat diambil hanya berdasarkan pada data yang terkumpul melalui kuesioner tersebut. Kuesioner penelitian ini juga memiliki keterbatasan 
yaitu terkadang jawaban yang diberikan oleh responden tidak menunjukkan keadaan yang sebenarnya.

\section{Saran}

Berdasarkan hasil analisa penelitian yang dilakukan, maka saran yang dapat diberikan sebagai berikut. Roy Sentoso Collection Yogyakarta perlu meningkatan upaya dalam memenuhi semua kebutuhan karyawan dengan baik dan tepat seperti melaksanakan program pelatihan mengacu dengan SOP yang ada, gaji selalu diberikan tepat waktu, menyediakan fasilitas-fasilitas untuk menunjang kelancaran dalam bekerja, sehingga kepuasan kerja karyawan semakin meningkat. Saran bagi Peneliti Selanjutnya agar dapat menambahkan variabel diluar penelitian yang dapat mempengaruhi kepuasan kerja karyawan. Penelitian selanjutnya dapat mengambil sampel yang lebih besar daripada sampel yang ada dalam penelitian ini sehingga penelitian selanjutnya diharapkan akan lebih valid. Disarankan untuk penelitian selanjutnya untuk menambah faktor lain yang sekiranya memperkuat kepuasan kerja. Selain itu, peneliti selanjutnya dapat mengambil sampel yang lebih besar dari pada penelitian ini.

\section{DAFTAR PUSTAKA}

Arikunto, S. (2013). Prosedur Penelitian Suatu Pendekatan Praktik (Ed Revisi). Rineka Cipta.

Asriani, A., Mintarti, S., \& ZA, S. (2020). Pengaruh Gaya Kepemimpinan Transformasional dan Budaya Organisasi terhadap Kinerja dan Kepuasan Kerja sebagai variabel intervening. Jurnal Bisnis Dan Manajemen, 16(3), 217-234.

Dessler, G. (2010). ManajemenSumber Daya Manusia (Edisi 10). PT Indeks.

Ghozali, I. (2016). Aplikasi Analisis Multivariete Dengan Program IBM SPSS 23 (Edisi 8). Badan Penerbit Universitas Diponegoro.

Hasibuan, M. (2011). Manajemen Sumber dan Daya Manusia (Ed Revisi). Bumi Aksara. Lodjo, F. S. (2013). Pengaruh Pelatihan, Pemberdayaan dan Efikasi Diri Terhadap Kepuasan Kerja. Jurnal EMBA: Jurnal Riset Ekonomi, Manajemen, Bisnis Dan Akuntansi, 1(3), 747-755.

Lumentut, M. D. ., \& Dotulong, L. O. . (2015). Pengaruh Motivasi, Disiplin dan Lingkungan Kerja terhadap Kepuasan Kerja Karyawan pada PT Bank Sulut Cabang Airmadidi. Jurnal EMBA: Jurnal Riset Ekonomi, Manajemen, Bisnis Dan Akuntansi, 3(1), 74-85.

Martoyo, S. (1987). Manajemen Sumber Daya Manusia. BPFE.

Mondy, R. W. (2008). Human Resource Management. (Edisi 10). PT Gelora Aksara Pratama.

Nitisemito, A. S. (1996). Manajemen dan Sumber Daya Manusia. BPFE Universitas Gajah Mada.

Potale, R., \& Uhing, Y. (2015). Pengaruh Kompensasi dan Stres Kerja terhadap Kepuasan Kerja Karyawan pada PT. Bank Sulut Cabang Utama Manado. Jurnal EMBA: Jurnal Riset Ekonomi, Manajemen, Bisnis Dan Akuntansi, 3(1), 63-73.

Priyatno, D. (2014). SPSS 22 Pengola Data Terpraktis. ANDI.

Qarismail, T., \& Prayekti, P. (2020). Pengaruh Gaya Kepemimpinan Transformasional, Motivasi dan Disiplin Kerja terhadap Kepuasan Kerja Karyawan. Jurnal Bisnis Dan Manajemen, 16(2), 115-129.

Reksohadiprodjo, S., \& Gitosudarmo, I. (2009). Manajemen Produksi. BPFE.

Rivai, V. (2004). Manajemen Sumber Daya Manusia Untuk Perusahaan: Dari Teori Ke Praktik. PT. Raja Grafindo Persada.

Sastrohadiwiryo, B. S. (2003). Manajemen Tenaga Kerja Indonesia (edisi 2). PT. Bumi 


\section{Aksara.}

Simamora, H. (1995). Manajemen Sumber Daya Manusia (Edisi 2). STIE YKPN.

Sunyoto, D. (2013). Analisis Regresi dan Uji Hipotesis. CAPS.

Trawardani, I. B., Prasetya, A., \& Mayowan, Y. (2015). Pengaruh Pelatihan terhadap Kemampuan Kerja yang Berdampak pada Kinerja Karyawan (Studi Pada Karyawan PT Bank Rakyat Indonesia (Pesero) Tbk Cabang Lumajang). Jurnal Administrasi Bisnis, 29(1), 51-58.

Wibowo, M., Musadieq, M. Al, \& Nurtjahjono, G. E. (2014). Pengaruh Lingkungan Kerja terhadap Kepuasan Kerja Karyawan (Studi pada Karyawan PT . Telekomunikasi Indonesia Tbk . Kandatel Malang). Jurnal Administrasi Bisnis, 16(1), 1-9.

Widodo. (2015). Manajemen Pengembangan Sumber Daya Manusia. Pustaka Pelajar. 